\title{
PENERAPAN MPK-BPKB DALAM MENINGKATKAN MOTIVASI DAN HASIL BELAJAR SISWA PADA MATA PELAJARAN PKK PROGRAM KEAHLIAN DPIB DI SMK DIY
}

\author{
Komang Ari Switara \\ Pendidikan Teknik Sipil dan Perencanaan, FT, UNY \\ Email: Komang.ari2016@student.uny.ac.id
}

\begin{abstract}
ABSTRAK
Kajian ini bertujuan untuk: (1) mendeskripsikan pelaksanaan MPK-BPKB pada mata pelajaran PKK di kelas XI DPIB SMKN 2 Depok, (2) apakah pelaksanaan MPK-BPKB meningkatkan motivasi siswa pada mata pelajaran PKK di kelas XI DPIB SMKN 2 Depok, dan (3) apakah pelaksanaan MPK-BPKB meningkatkan hasil belajar siswa dalam belajar mata pelajaran PKK di kelas XI DPIB SMKN 2 Depok. Kajian ini merupakan Kuasi Eksperimen (Quasy Experiment). Subjek dari kajian ini adalah 30 siswa kelas XI DPIB SMK Negeri 2 Depok sebagai kelas eksperimen dan 29 siswa kelas XI DPIB SMK Negeri 1 Seyegan sebagai kelas kontrol. Teknik pengumpulan data dalam kajian ini menggunakan soal tes dan angket. Metode yang digunakan dalam analisis data yaitu metode analisis deskriptif, uji Independent sample $t$ test. Hasil kajian menunjukkan bahwa keseluruhan dari pelaksanaan tahap MPK-BPKB sudah memadai dengan nilai rerata terdapat pada bentang kriteria 2,25 $>X \geq 1,5$. Hasil analisis rerata motivasi belajar pada kelas eksperimen adalah sebesar 2,04 (dengan rentang $0-3$ ) yang artinya MPK-BPKB memotivasi siswa dalam belajar mata pelajaran PKK. Hasil perhitungan pretest nilai rerata kelas eksperimen adalah 45,33 lebih tinggi dari kelas kontrol yaitu 42,17, sedangkan untuk hasil perhitungan posttest nilai rerata kelas eksperimen adalah 76,33 masih lebih tinggi dari kelas kontrol yaitu 51,83. Setelah dilakukan uji persyaratan analisis yang hasilnya normal dan homogen maka selanjutnya dilakukan uji hipotesis pada kedua kelas dengan hasil uji t menggunakan cara manual maupun SPSS v.22 untuk posttest thitung sebesar $(7,565)>t_{\text {tabel }}(1,687)$ maka Ho ditolak dan Ha diterima. Maka dari itu penggunaan MPK-BPKB lebih efektif dalam meningkatkan hasil belajar siswa dan dapat difungsikan juga untuk masyarakat banyak dengan produk yang sesuai dengan program keahlian yang di emban.
\end{abstract}

Kata kunci: Motivasi, MPK-BPKB, PKK

\section{ABSTRACT}

This study aims to: (1) describe the implementation of MPK-BPKB in PKK subjects in class XI DPIB $S M K N 2$ Depok, (2) describe whether the implementation of MPK-BPKB increases student motivation in PKK subjects in class XI DPIB SMKN 2 Depok, and (3) describe whether the implementation of the MPK-BPKB improves student learning outcomes in learning PKK subjects in class XI DPIB SMKN 2 Depok. This research is a quasi-experimental study (Quasy Experiment). The subjects of this study were chosen randomly with the result 30 students of class XI DPIB of SMK Negeri 2 Depok as the experimental class and 29 students of class XI DPIB of SMK Negeri 1 Seyegan as the control class. Data collection techniques in this study used test questions and questionnaires. The method used in data analysis is descriptive analysis method, Independent sample t test The results showed that the overall implementation of the MPK-BPKB stage was sufficient with the average value found in the range of criteria $2.25>X \geq 1.5$. The result of the average analysis of learning motivation in the experimental class is 2.04 (with a range of $0-3$ ), which means that the MPK-BPKB motivates students to learn PKK subjects. The results of the pre-test calculation of the experimental class mean value was 45.33 higher than the control class that was 42.17, while for the post-test results the mean score of the experimental class was 76.33 still higher than the control class that was 51.83. After testing the analysis requirements which results are normal and homogeneous then the hypothesis test is then performed on both classes with $t$ test results using manual or SPSS program v.22 for the post-test $t$ Count of $(7,565)>t_{\text {table }}(1,687)$ then Ho is rejected and Ha is accepted. Therefore the use of MPK-BPKB is more effective in improving student learning outcomes and student learning functioned for the community at large with products in accordance with the expertise program carried.

Keywords: Motivation, $M P K-B P K B, P K K$ 


\section{PENDAHULUAN}

Sekolah Menengah Kejuruan merupakan salah satu wadah untuk menyiapkan sumber daya manusia yang berkualitas dan memiliki daya saing yang tinggi. Ada beberapa program keahlian SMK diantaranya adalah teknik konstruksi dan properti yang memiliki kompetensi keahlian yaitu Konstruksi Gedung Sanitasi dan Perawatan (KGSP) dan Desain Pemodelan dan Informasi Bangunan. Pada kurikulium 2013 untuk mempersiapkan lulusan yang siap kerja dan mampu bersaing di dunia industri terdapat mata pelajaran Prakarya dan Kewirausahaan (Pkwu) tetapi hal ini mengalami perubahan pada kurikulum 2013 revisi menginstruksikan untuk merubah mata pelajaran Prakarya dan Kewirausahaan (Pkwu) menjadi Produk Kreatif dan Kewirausahaan (PKK). Perubahan ini juga berlaku pada SMK N 2 Depok dan SMKN 1 Sayegan, Selama ini, mata pelajaran PKK untuk siswa SMKN 2 Depok dan SMKN 1 Seyegan belum seutuhnya sesuai dengan potensi dan keunggulan dari masing-masing program keahlian yang ada di sekolah. Output pembelajaran selama ini, hanya sebatas pada kerajinan tangan dari limbah ataupun budidaya yang sama sekali tidak ada kaitannya dengan program keahlian, misal kompetensi keahlian DPIB. Berdasarkan Permendikbud Nomor 65 tahun 2013 tentang Standar Proses, model pembelajaran yang diutamakan dalam implementasi kurikulum 2013 adalah model pembelajaran inkuri, model pembelajaran diskoveri, model pembelajaran berbasis proyek, dan model pembelajaran berbasis permasalahan (Mulyasa, 2015: 143). Menurut Thomas (2000) dikutip dari Made Wena (2009:145), model pembelajaran berbasis proyek mempunyai beberapa prinsip diantaranya prinsip sentralis (centrality), prinsip pertanyaan pendorong/penuntun (driving question), prinsip investigasi konstruktif (constructive investigation), prinsip otonomi (autonomy), dan prinsip (realistic). Penggunaan Model Pembelajaran Kewirausahaan Berbasis Proyek Konstruksi Bangunan (MPKBPKB) diharapkan dapat meningkatkan kualitas belajar siswa pada mata pelajaran Produk Kreatif dan Kewirausahaan (PKK) serta diharapkan ke depan sesuai dengan kebutuhan guru dan SMK. Berdasarkan kondisi tersebut, perlu suatu upaya nyata untuk mengoptimalkan beberapa potensi yang sudah dimiliki oleh sekolah dari segi implementasi pembelajaran Produk Kreatif dan Kewirausahaan (PKK) yang match dengan kompetensi keahlian serta kebutuhan dunia kerja. Oleh karena itu, diperlukan riset pengembangan berupa implementasi Model Pembelajaran Kewirausahaan Berbasis Proyek Konstruksi Bangunan (MPK-BPKB) guna meningkatkan kompetensi lulusan dan membekali diri sebagai wirausahawan. Berdasarkan kondisi SMKN 2 Depok dan SMKN 1 Seyegan di atas, perlu suatu upaya nyata untuk mengoptimalkan beberapa potensi yang sudah dimiliki sekolah maupun program keahlian DPIB. Oleh karena itu, diperlukan kajian "Penerapan MKP-BPKB dalam Meningkatkan Motivasi dan Hasil Belajar Siswa pada Mata Pelajaran PKK Program Keahlian DPIB di SMK DIY".

Selaras dengan kondisi di atas, tujuan dari kajian ini adalah mendeskripsikan keterlaksanaan MPK-BPKB pada mata pelajaran PKK di kelas IX DPIB SMKN 2 Depok, dan mendeskripsikan pengarush 
MPK-BPKB dalam meningkatkan motivasi dan hasil belajar siswa pada mata pelajaran Produk Kreatif dan Kewirausahaan di kelas XI DPIB SMKN 2 Depok. Kajian ini diharapkan dapat bermanfaat bagi siswa dalam meningkatkan motivasi dan hasil belajar, bagi guru sebagai motivasi dalam meningkatkan keterampilan yang bervariasi yang dapat memperbaiki sistem pembelajaran dan bagi sekolah dapat memberikan sumbangan yang baik dalam rangka perbaikan proses pembelajaran untuk dapat meningkatkan prestasi siswa.

\section{METODE}

Kajian ini merupakan eksperimen semu (quasi experiment) karena tidak semua variabel yang muncul dan kondisi eksperimen dapat diatur dan dikontrol secara penuh (Campbell \& Stanley, 1963: 34). Sugiyono (2007: 107) mendefinisikan bahwa penelitian eksperimen yaitu penelitian yang digunakan untuk mencari pengaruh perlakuan tertentu terhadap yang lain dalam kondisi yang terkendali.

Kajian ini dilaksanakan di SMKN 2 Depok sebagai kelas eksperimen yang berlokasi di Kampung Mrican, Caturtunggal, Depok, Santren, Caturtunggal, Kec. Depok, Kota Yogyakarta, Daerah Istimewa Yogyakarta 55281 dan di SMKN 1 Seyegan sebagai kelas kontrol yang berlokasi di Jalan Kebonagung, KM. 8,5, Margomulyo, Seyegan, Mriyan, Margomulyo, Kec. Seyegan, Kabupaten Sleman, Daerah Istimewa Yogyakarta 55561. Kajian ini fokus pada penerapan MPK-BPKB pada program keahlian Desain Pemodelan dan Informasi Bangunan (DPIB). Kajian ini dilaksanakan pada semester gasal tahun pelajaran 2019/2020 dari bulan Juli sampai bulan Oktober 2019.
Subyek kajian ini adalah siswa dan satu guru kelas XI pada program keahlian Desain Pemodelan dan Informasi Bangunan (DPIB) yang mendapatkan mata pelajaran Produk Kreatif dan Kewirausahaan tahun ajaran 2019/2020. Kajian ini menggunakan 2 kelas yang dimana pada kelas XI DPIB SMKN 2 Depok digunakan sebagai kelas eksperimen, sedangkan pada kelas XI DPIB SMKN 1 Seyegan digunakan sebagai kelas kontrol dengan jumlah siswa rata - rata sama yaitu 30 orang siswa.

Teknik pengumpulan data adalah cara yang digunakan oleh peneliti dalam mengumpulkan data kajian. Teknik pengumpulan data dalam guasi eksperiment ini adalah dengan menggunakan angket dan metode tes. Angket yang digunakan kajian ini adalah angket tertutup untuk mengumpulkan data yang difokuskan pada pelaksanaan tahap MPK-BPKB dan pengaruh MPK-BPKB terhadap motivasi belajar siswa pada mata pelajaran PKK kelas 11 DPIB di SMKN 2 Depok. Kriteria keberhasilan pelaksanaan tahapan - tahapan dan pengaruh MPK-BPKB terhadap motivasi belajar siswa pada mata pelajaran PKK di kelas 11 DPIB SMKN 2 Depok yang meliputi: 1) tahap persiapan, 2) tahap pelaksanaan, 3) tahap penilaian. Angket pelaksanaan tahap MPK-BPKB diisi oleh siswa, guru, dan peneliti yang terdiri dari 10 sampai 11 pertanyaan. Metode tes terdiri dari Pretest dan posttest terdiri dari 30 butir soal obyektif terkait dengan 3 mata pelajaran yang mencakup kemampuan berfikir tingkat tinggi dengan dasar pertanyaan dari KI dan KD pada masing masing mata pelajaran. Pada kajian ini, hanya menggunakan tes obyektif dengan bentuk pilihan ganda, sehingga hasil yang akan diperoleh akan tetap sama seperti 
jawaban peserta uji walaupun dengan pengoreksi yang berbeda.

Sugiyono (2006:152), berpendapat "Terdapat dua hal utama yang mempengaruhi kualitas data hasil penelitian, yaitu kualitas instrumen penelitian dan kualitas pengumpul data. Kualitas instrumen berkaitan dengan validitas dan realibilitas instrumen, sedangkan kualitas pengumpul data berkenaan dengan cara-cara yang digunakan untuk mengumpulkan data". Sesuai dengan teknik pengumpulan data yang digunakan maka instrumen yang digunakan dalam kajian ini berupa angket (kuesioner) dan instrumen tes. Angket yang digunakan adalah angket tertutup untuk mendapatkan data kuantitatif berupa ketercapaian pelaksanaan dan pengaruh MPK-BPKB terhadap motivasi belajar siswa kelas 11 DPIB SMKN 2 Depok. Instrumen tes dibutuhkan dalam suatu pengambilan data untuk memperoleh informasi seberapa pengaruh yang ditimbulkan terhadap kelompok yang memperoleh perlakuan.

Instrumen kajian yang digunakan ada dua yaitu instrumen angket/kuisioner dan instrumen tes. Kisi-kisi dan indikator angket merujuk pada pelaksanaan tahap tahap MPK-BPKB dan pengaruh MPKBPKB terhadap motivasi belajar siswa pada mata pelajaran PKK terdiri dari variabel pelaksanaan 10 tahap siswa oleh guru dan peneliti, variabel motivasi beljar oleh siswa, dan skala likert empat alternatif jawaban dari pernyataan/pernyataan pelaksanaan dan motivasi belajar siswa. Sedangkan untuk instrumen tes menggunakan dua tes yaitu tes awal atau pretest dan tes akhir atau posttest diberikan pada kelas eksperimen dan kelas control dalam bentuk pertanyaan pilihan ganda dengan 30 butir soal dari 3 mata pelajaran, sehingga hasil yang diperoleh akan tetap sama seperti jawaban peserta uji walaupun dengan pengoreksi yang berbeda.

Sesuai dengan teknik pengumpulan data yang digunakan, maka instrumen yang digunakan dalam kajian ini adalah berupa angket (kuesioner). Uji validitas instrumen yang dilakukan berkaitan dengan validitas isi didasarkan pada pertimbangan logis, yaitu melalui expert judgment. Uji validitas yang dilakukan adalah dengan mengkonsultasikan instrumen yang sudah ada kepada ahli (expert judgement) yang dilakukan oleh dua dosen ahli evaluasi pendidikan dan ahli pendidikan vokasi. Hasil dari dua orang dosen penguji adalah instrumen layak untuk digunakan.

Instrumen yang reliabel adalah instrumen yang bila digunakan beberapa kali untuk mengukur obyek yang sama, akan menghasilkan data yang sama (Sugiyono 2016: 173). Dalam mengukur reliabilitas instrumen kajian ini menggunakan metode Cronbach's Alpha dengan program SPSS v.22. metode inicocok digunakan untuk mencari reliabilitas instrumen yang skornya bukan 1 dan 0, misalnya angket atau soal bentuk uraian (Arikunto, 2013: 239). Berikut ini Rumus Alpha menurut Retnawati (2016: 91), yaitu :

$$
\propto=\left(\frac{k}{(k-1)}\right)\left(1-\frac{\left(\sum \sigma_{i}^{2}\right.}{\sigma_{t}^{2}}\right)
$$

$\alpha=$ koefisien reliabilitas instrumen

$\mathrm{k}$ = banyaknya butir pertanyaan dalam instrumen

$\left(\Sigma \sigma_{\mathrm{i}}^{2}\right)=$ jumlah varians butir instrument $\sigma_{\mathrm{t}}^{2} \quad=$ varians skor total

Langkah yang ditempuh dalam analisis data angket menggunakan statistik 
deskriptif yaitu meliputi perhitungan nilai rata-rata atau mean $(\mathrm{M})$, dan standard deviasi (SD) perolehan skor responden pada setiap aspek. Rerata atau Mean $(\bar{X})$ merupakan teknik penjelasan yang didasarkan atas nilai rata - rata kelompok tersebut (Sugiyono, 2011: 45). Mean adalah nilai rata - rata dari suatu kelompok yang diteliti dan perhitunannya dapat menggunakan rumus menurut Sugiyono (2011 : 49) :

$$
\bar{X}=\sum_{i=1}^{n} X_{i} / n
$$

Di mana :

$\bar{X} \quad=$ Mean atau rata - rata

$X_{i} \quad=$ Nilai $\mathrm{x}$ ke 1 sampai ke $\mathrm{n}$

$\mathrm{n} \quad=$ jumlah individu

$S d=\sqrt{\frac{1}{n-1} \sum_{i=1}^{n}(X i-\bar{X})^{2}}$

Di mana :

Sd $\quad=$ Standar Deviasi

$\bar{X} \quad=$ Mean atau rata - rata

$X_{i} \quad=$ Nilai data ke 1

$\mathrm{n} \quad=$ Banyaknya data

Analisis data dilakukan dengan cara menentukan variabel idealnya yang dapat dihitung dengan norma sebagai berikut :

$$
\begin{aligned}
& \bar{X} \text { ideal }=\frac{1}{2}(\mathrm{ST}+\mathrm{SR}) \\
& \text { SDideal }=\frac{1}{6}(\mathrm{ST}-\mathrm{SR})
\end{aligned}
$$

Gambaran penilaian pelaksanaan dan motivasi belajar menggunakan MPK-BPKB pada mata pelajaran PKK ditinjau secara keseluruhan, terlebih dahulu menghitung mean ideal $\left(\mathrm{M}_{\mathrm{i}}\right)$ dan standar deviasi $\left(\mathrm{SD}_{\mathrm{i}}\right)$. Dari 9 sampai 11 butir pertanyaan yang ada dengan skor intensitas pelaksanaan dari 0-3 diperoleh parameter sebagai berikut:

Skor Tertinggi ideal $=3$
Skor Terendah ideal $=0$

Mean ideal $=\frac{1}{2}($ skor tertinggi + skor terendah

$$
=\frac{1}{2}(3+0)=1,5
$$

$\mathrm{SD}$ ideal $=\frac{1}{6}($ skor tertinggi - skor terendah)

$$
=\frac{1}{6}(3-0)=0,5
$$

Untuk mendapatkan kedudukan obyek kajian digunakan kriteria dengan menggunakan interval kelas sebagai berikut (Sukardi, 2011: 35).

Jumlah perkiraan interval

$=\frac{(\text { nilai terbesar data }- \text { nilai terkecil dalam data })}{\text { kelas yang diinginkan }}$

Kategori tersebut didasarkan pada Mean ideal $\left(\mathrm{M}_{\mathrm{i}}\right)$ dan Standar Deviasi ideal $\left(\mathrm{SD}_{\mathrm{i}}\right)$ dilakukan dengan ketentuan sebagai berikut:

Kategori sangat memadai

$=\mathrm{X}>\mathrm{Mi}+1,5(\mathrm{SDi})$

Kategori memadai

$=\mathrm{Mi} \leq \mathrm{X}<\mathrm{Mi}+1,5(\mathrm{SDi})$

Kategori kurang memadai

$=\mathrm{Mi}-1,5(\mathrm{SDi}) \leq \mathrm{X}<\mathrm{Mi}$

Kategori sangat kurang memadai

$=\mathrm{X}<\mathrm{Mi}-1,5(\mathrm{SDi})$

nilai rata - rata total dan standard deviasi menjadi kategori kelayakan MPKBPKB pada mata pelajaran PKK kelas 11 DPIB pada gambar kurva - kurva baku normal sebagai berikut. 


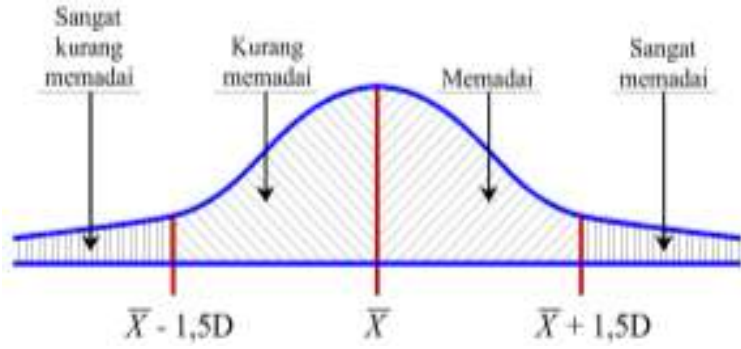

Gambar 1. Grafik Distribusi Normal Pelaksanaan 10 tahap oleh Guru, Siswa, dan Peneliti.

Sebelum dilakukan pengujian analisis data, kajian ini terlebih dahulu diadakan uji persyaratan analisis yaitu pengujian normalitas dan homogenitas pada kelompok eksperimen dan kelompok kontrol dengan menggunakan program komputer SPSS. Untuk uji hipotesis kajian menggunakan program SPSS versi 22. Pengujian ini menggunakan Independent Samples T-Test karena data berasal dari 2 sampel yang berbeda.

\section{HASIL DAN PEMBAHASAN}

Pelaksanaan MPK-BPKB pada kelas XI DPIB SMKN 2 Depok yang digunakan sebagai kelas eksperimen dibagi menjadi 3 tanggapan terkait dengan perlaksanaan MPK-BPKB oleh Guru, Siswa, dan Peneliti.
Tanggapan siswa terhadap pelaksanaan Model Pembelajaran Berbasis Proyek Konstruksi Bangunan (MPKBPKB) ditinjau secara keseluruhan diukur menggunakan angket tertutup. Pertanyaan dalam angket tertutup meliputi pelaksanaan 10 tahap dari MPK-BPKB yang sudah diajarkan oleh guru kepadanya. Penskoran angket tertutup dengan jumlah sebanyak 10 butir pertanyaan menggunakan intensitas pelaksanaan dengan skala skor $3=$ Penjelasan sangat memadai, $2=$ Penjelasan cukup memadai, 1=Ada penjelasan namun belum memadai, dan $0=$ Belum ada penjelasan, sehingga berdasarkan skor tersebut maka penilaian pelaksanaan MPK-BPKB pada mata pelajaran PKK ditinjau secara keseluruhan pelaksanaan memiliki rentang skor 0 sampai 30, untuk jumlah responden dalam pengisian angket sebanyak 30 siswa kelas eksperimen.

Untuk mengetahui skor data penilaian pelaksanaan MPK-BPKB pada mata pelajaran PKK di kelas XI DPIB SMK 2 Depok baik secara per-tahapan maupun secara keseluruhan disajikan dalam tabel 1 . sebagai berikut.

Tabel 1. Tanggapan Siswa terhadap Pelaksanaan Tahap MPK-BPKB yang dilakukan oleh Guru per tahapan.

\begin{tabular}{clcc}
\hline No & \multicolumn{1}{c}{ Tahap } & $\begin{array}{c}\text { Jumlah } \\
\text { Skor }\end{array}$ & Rerata \\
\hline 1 & Guru menjelaskan pengertian, tujuan, dan cakupan materi PKK. & 62 & 2,07 \\
2 & $\begin{array}{l}\text { Guru menjelaskan konsep, nilai-nilai, dan tahapan MPK-BPKB. } \\
\text { Guru menjelaskan pengertian dan tujuan, dan tahapan pengajuan HAKI. }\end{array}$ & 44 & 1,47 \\
4 & $\begin{array}{l}\text { Guru menjelaskan kriteria pemilihan topik proyek } \\
\text { Guru menjelaskan kegunaan dan komponen yang ada dalam rencana }\end{array}$ & 52 & 1,60 \\
5 & $\begin{array}{l}\text { usaha (bussnis plan) } \\
\text { Guru menjelaskan kriteria penilaian dan cara mempresentasikan rencana }\end{array}$ & 50 & 1,63 \\
7 & $\begin{array}{l}\text { Gsaha (bussnis plan) } \\
\text { puru menjelaskan hal-hal yang perlu disiapkan dalam kebutuhan }\end{array}$ & 46 & 1,67 \\
8 & $\begin{array}{l}\text { Guru menjelaskan cara pengerjaan proyek (untuk menghasilkan } \\
\text { produk/jasa yang dirancang siswa) }\end{array}$ & 43 & 1,53 \\
9 & $\begin{array}{l}\text { Guru menjelaskan pengemasan produk akhir proyek untuk } \\
\text { dipresentasikan }\end{array}$ & 49 & 1,63 \\
10 & Guru menjelaskan kriteria penilaian produk akhir proyek & 42 & 1,40 \\
\hline
\end{tabular}




\begin{tabular}{lccc}
\hline No & Tahap & $\begin{array}{c}\text { Jumlah } \\
\text { Skor }\end{array}$ & Rerata \\
\hline
\end{tabular}

Tabel 1 menunjukkan tanggapan siswa terhadap pelaksanaan MPK-BPKB berada pada rentang nilai terendah dengan jumlah skor 42 dengan rerata 1,40 pada tahap guru menjelaskan kriteria penilaian produk akhir proyek sampai pada nilai tertinggi dengan jumlah skor 62 dengan nilai rerata terbesar 2,07 pada tahap guru menjelaskan pengertian, tujuan, dan cakupan materi PKK, dengan nilai rerata secara keseluruhan sebesar 1,62. Dengan demikian, tanggapan siswa terhadap pelaksanaan MPK-BPKB ada dalam rentang $(2,25>X \geq 1,5)$ atau penjelasan cukup memadai.

Tabel 2. Kategori Penilaian Pelaksanaan MPK-BPKB oleh Siswa pada Mata Pelajaran PKK ditinjau secara Keseluruhan.

\begin{tabular}{cllcc}
\hline No & Kriteria & Kategori & \multicolumn{2}{c}{ Frekuensi } \\
& & & F & \% \\
\hline 1 & $\mathrm{X}>2,25$ & Penjelasan sangat memadai & 3 & 10 \\
2 & $2,25>\mathrm{X} \geq 1,5$ & Penjelasan cukup memadai & 15 & 50 \\
3 & $1,5>\mathrm{X} \geq 0,75$ & Ada penjelasan namun belum memadai & 12 & 40 \\
4 & $0,75>\mathrm{X}$ & Belum ada penjelasan & 0 & 0 \\
\hline & & Jumlah & $\mathbf{3 0}$ & $\mathbf{1 0 0}$
\end{tabular}

Berdasarkan tabel 2 Sebaran skor penilaian pelaksanaan MPK-BPKB pada mata pelajaran PKK ditinjau dari siswa kelas XI DPIB SMKN 2 Depok, maka diperoleh histogram sebagai berikut :

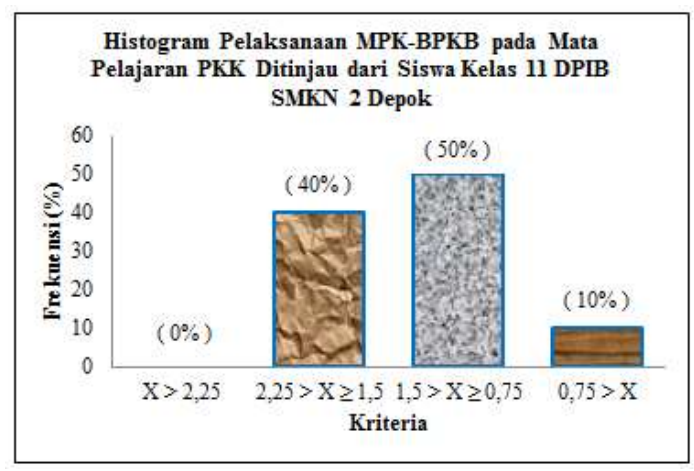

Gambar 2. Histogram Pelaksanaan MPK-BPKB pada Mata Pelajaran PKK Ditinjau dari Siswa Kelas XI DPIB SMKN 2 Depok.

Keterangan :

$$
\begin{aligned}
& =\text { Belum ada penjelasan } \\
= & \text { Ada penjelasan namun belum } \\
& \text { memadai } \\
= & \text { Penjelasan cukup memadai }
\end{aligned}
$$


secara keseluruhan oleh siswa berbeda pada kategori penjelasan sangat memadai sebanyak 3 siswa (10\%), kategori penjelasan cukup memadai sebanyak 15 siswa (50\%), kategori ada penjelasan namun belum memadai sebanyak 12 siswa $(40 \%)$, dan kategori belum ada penjelasan sebanyak 0 siswa $(0 \%)$.

Berdasarkan deskripsi dan interpretasi data di atas diperoleh hasil bahwa: nilai rata - rata pelaksanaan MPK-BPKB pada mata pelajaran PKK di kelas XI DPIB SMKN 2 Depok secara keseluruhan adalah 1,62. Dengan demikian dapat disimpulkan bahwa pelaksanaan MPK-BPKB pada mata pelajaran PKK di kelas XI DPIB SMKN 2 Depok ditinjau secara keseluruhan termasuk dalam kategori penjelasan cukup memadai yang artinya guru memberikan penjelasan kepada siswa cukup memadai.

Tabel 3. Tanggapan Siswa terhadap Motivasi Belajar pada Mata Pelajaran PKK.

\begin{tabular}{clcc}
\hline No & \multicolumn{1}{c}{ Tahap } & $\begin{array}{c}\text { Jumlah } \\
\text { Skor }\end{array}$ & Rerata \\
\hline 1 & $\begin{array}{l}\text { Mengidentifikasi kebutuhan jenis produk yang dibutuhkan oleh pelaku usaha } \\
\text { konstruksi bangunan }\end{array}$ & 53 & 1,77 \\
2 & $\begin{array}{l}\text { Menentukan topik kebutuhan jenis produk yang dibutuhkan oleh pelaku usaha } \\
\text { konstruksi bangunan }\end{array}$ & 52 & 1,73 \\
3 & Mewawancarai pelaku usaha konstruksi bangunan & 61 & 2,03 \\
4 & Menyusun rencana usaha yang realistik / nyata & 69 & 2,30 \\
5 & Mengerjakan proyek dengan baik & 65 & 2,17 \\
6 & Mempresentasikan proyek dengan baik & 72 & 2,40 \\
7 & Memperbaiki hasil akhir proyek sesuai masukan guru / tim penilai & 68 & 2,27 \\
8 & Mengamati hasil proyek dalam bentuk paket yang siap dipasarkan / dijual & 60 & 2,00 \\
9 & Mengajukan hasil proyek akhir untuk memperoleh hak paten & 52 & 1,73 \\
10 & Merencanakan pekerjaan / topik-topik proyek lanjutan dari topik yang sudah & 54 & 1,80 \\
& selesai dikerjakan & 50 & 2,27 \\
\hline
\end{tabular}

Tabel 3 menunjukkan tanggapan siswa terhadap motivasi belajar siswa berada pada rentang nilai terendah dengan jumlah skor 52 dengan rerata 1,73 pada pertanyaan menentukan topik kebutuhan jenis produk yang dibutuhkan oleh pelaku usaha konstruksi bangunan dan pada mengajukan hasil proyek akhir untuk
Pengaruh MPK-BPKB terhadap motivasi belajar siswa ditinjau secara keseluruhan diukur menggunakan angket tertutup. Penskoran angket tertutup dengan jumlah 11 butir pertanyaan menggunakan intensitas jawaban dengan skala skor $3=$ Sangat memotivasi, 2=Memotivasi, $1=$ Sedikit memotivasi, dan $0=$ Tidak memotivasi, sehingga berdasarkan skor tersebut maka penilaian angket motivasi siswa ditinjau secara keseluruhan memiliki rentang skor 0 sampai 33 .

Ketentuan pengategorian untuk mengetahui skor data penilaian motivasi belajar siswa pada mata pelajaran PKK di kelas XI DPIB SMK 2 Depok baik secara per-pertanyaan maupun secara keseluruhan disajikan dalam tabel 3 sebagai berikut.

memperoleh hak paten sampai pada nilai tertinggi dengan jumlah skor 72 dengan nilai rerata 2,40 pada pertanyaan mempresentasikan proyek dengan baik, dengan nilai rerata secara keseluruhan sebesar 2,04. Dengan demikian, tanggapan siswa terhadap angket motivasi siswa ada 
dalam rentang $(2,25>\mathrm{X} \geq 1,5)$ atau memotivasi.

Tabel 4. Kategori Penilaian Motivasi Belajar Siswa pada Mata Pelajaran PKK Ditinjau secara Keseluruhan.

\begin{tabular}{cllcc}
\hline \multirow{2}{*}{ No } & \multirow{2}{*}{ Kriteria } & \multicolumn{1}{c}{ Kategori } & Frekuensi \\
& & & F & \% \\
\hline 1 & $X>2,25$ & Sangat memotivasi & 20 & 33,3 \\
2 & $2,25>X \geq 1,5$ & Memotivasi & 0 & 66,7 \\
3 & $1,5>X \geq 0,75$ & Sedikit memotivasi & 0 & 0 \\
4 & $0,75>X$ & Tidak memotivasi & 0 \\
\hline
\end{tabular}

Berdasarkan tabel 4 Sebaran skor motivasi siswa pada mata pelajaran PKK ditinjau dari siswa kelas XI DPIB SMKN 2 Depok, maka diperoleh histogram sebagai berikut :

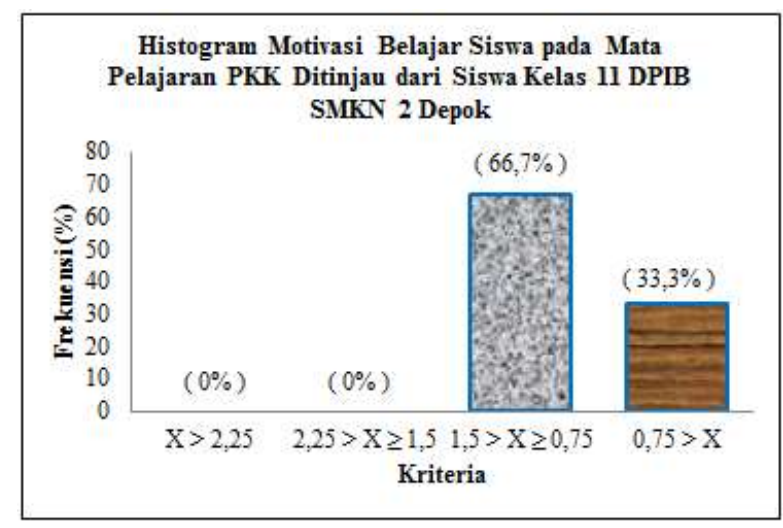

Gambar 3. Histogram Motivasi Belajar Siswa pada Mata Pelajaran PKK Ditinjau secara Keseluruhan.

Keterangan :

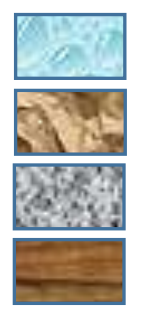

$=$ Tidak memotivasi

$=$ Sedikit memotivasi

$=$ Memotivasi

$=$ Sangat memotivasi

Berdasarkan tabel 4 dan gambar 3 di atas, dapat diketahui penilaian angket motivasi belajar siswa pada mata pelajaran PKK di kelas XI DPIB SMK 2 Depok ditinjau secara keseluruhan oleh siswa berbeda pada kategori sangat memotivasi sebanyak 10 siswa $(33,3 \%)$, kategori memotivasi sebanyak 20 siswa $(66,7 \%)$, kategori sedikit memotivasi sebanyak 0 siswa $(0 \%)$, dan kategori tidak memotivasi sebanyak 0 siswa $(0 \%)$.
Berdasarkan deskripsi dan interpretasi data di atas diperoleh hasil bahwa: nilai rata - rata motivasi belajar siswa pada mata pelajaran PKK di kelas XI DPIB SMKN 2 Depok secara keseluruhan adalah 2,04. Dengan demikian dapat disimpulkan bahwa motivasi belajar siswa mata pelajaran PKK di kelas XI DPIB SMKN 2 Depok ditinjau secara keseluruhan termasuk dalam kategori memotivasi yang artinya siswa termotivasi dengan mata pelajaran PKK karena menggunakan MPK-BPKB.

Pengaruh MPK-BPKB terhadap hasil belajar siswa diukur menggunakan pretest dan posttest yang terdiri dari 30 butir soal yang mewakili 25 kompetensi dasar dan kemampuan berfikir tingkat tinggi. Sebelum penerapan MPK-BPKB diberikan pretest untuk mengukur kemampuan awal dari seluruh siswa baik yang akan digunakan sebagai kelas eksperimen maupun yang akan digunakan sebagai kelas kontrol. Dalam kajian ini hasil pretest digunakan untuk menentukan siswa yang memiliki kemampuan yang sama yang akan dijadikan sebagai obyek kajian, sebab kedua kelas kajian sama-sama belum mendapatkan materi yang digunakan dalam kajian.

Data hasil Pretest mengunakan skala nilai $0-100$. Berikut adalah daftar hasil pretest yang dilakukan pada kelas eksperimen dan kelas kontrol. 
Tabel 5. Data Hasil Pretest pada Kelas Eksperimen dan Kelas Kontrol.

\begin{tabular}{|c|c|c|}
\hline \multirow[b]{2}{*}{ No. } & \multicolumn{2}{|c|}{ Nilai Pre-test } \\
\hline & $\begin{array}{c}\text { SMKN } 2 \\
\text { Depok } \\
\text { (Eksperimen) }\end{array}$ & $\begin{array}{c}\text { SMKN } 1 \\
\text { Seyegan } \\
\text { (Kontrol ) }\end{array}$ \\
\hline 1. & 60,00 & 56,67 \\
\hline 2. & 53,33 & 53,33 \\
\hline 3. & 53,33 & 53,33 \\
\hline 4. & 50,00 & 50,00 \\
\hline 5. & 50,00 & 50,00 \\
\hline 6. & 50,00 & 46,67 \\
\hline 7. & 50,00 & 46,67 \\
\hline 8. & 50,00 & 43,33 \\
\hline 9. & 46,67 & 40,00 \\
\hline 10. & 46,67 & 40,00 \\
\hline 11. & 43,33 & 40,00 \\
\hline 12. & 43,33 & 40,00 \\
\hline 13. & 43,33 & 36,67 \\
\hline 14. & 40,00 & 36,67 \\
\hline 15. & 40,00 & 36,67 \\
\hline 16. & 40,00 & 36,67 \\
\hline 17. & 40,00 & 36,67 \\
\hline 18. & 36,67 & 33,33 \\
\hline 19. & 36,67 & 33,33 \\
\hline 20. & 33,33 & 33,33 \\
\hline & Valid $\quad 20$ & 20 \\
\hline $\mathrm{N}$ & Missing $\quad 0$ & 0 \\
\hline Rerata & a $\quad 45,33$ & 42,17 \\
\hline Standar & 6,79 & 7,36 \\
\hline Deviasi & & \\
\hline Nilai & 33,33 & 33,33 \\
\hline Terendah & & \\
\hline Nilai & 60,00 & 56,67 \\
\hline Tertinggi & & \\
\hline
\end{tabular}

Berdasarkan data pada tabel 5 di atas, untuk kelas eksperimen memperoleh nilai rerata sebesar 45,33 sedangkan kelas kontrol memperoleh nilai rerata sebesar 42,17, nilai standar deviasi kelas eksperimen sebesar 6,79 sedangkan kelas kontrol memperoleh sebesar 7,36, kelas eksperimen memiliki nilai varian sebesar 46,08 sedangkan kelas kontrol memiliki nilai varian sebesar 54,12 , nilai terendah kelas eksperimen dan kelas kontrol adalah sama yaitu sebesar 33,33 dan nilai tertinggi kelas eksperimen sebesar 60,00 sedangkan nilai tertinggi kelas kontrol sebesar 56,67.

Data hasil Posttest mengunakan skala nilai $0-100$. Berikut adalah daftar hasil pretest yang dilakukan pada kelas eksperimen dan kelas kontrol.

Tabel 6. Data Hasil Posttest pada Kelas Eksperimen dan Kelas Kontrol.

\begin{tabular}{|c|c|c|}
\hline \multirow[b]{2}{*}{ No. } & \multicolumn{2}{|c|}{ Nilai Post-test } \\
\hline & $\begin{array}{c}\text { SMKN 2 } \\
\text { Depok } \\
\text { (Eksperimen) }\end{array}$ & $\begin{array}{c}\text { SMKN } 1 \\
\text { Seyegan } \\
\text { (Kontrol) } \\
\end{array}$ \\
\hline 1. & 83,33 & 63,33 \\
\hline 2. & 76,67 & 53,33 \\
\hline 3. & 73,33 & 36,67 \\
\hline 4. & 76,67 & 53,33 \\
\hline 5. & 93,33 & 56,67 \\
\hline 6. & 63,33 & 60,00 \\
\hline 7. & 83,33 & 40,00 \\
\hline 8. & 83,33 & 53,33 \\
\hline 9. & 83,33 & 56,67 \\
\hline 10. & 80,00 & 73,33 \\
\hline 11. & 76,67 & 53,33 \\
\hline 12. & 90,00 & 66,67 \\
\hline 13. & 70,00 & 33,33 \\
\hline 14. & 60,00 & 56,67 \\
\hline 15. & 83,33 & 46,67 \\
\hline 16. & 63,33 & 40,00 \\
\hline 17. & 86,67 & 43,33 \\
\hline 18. & 66,67 & 56,67 \\
\hline 19. & 76,67 & 53,33 \\
\hline 20. & 56,67 & 43,33 \\
\hline $\mathrm{N}$ & Valid $\quad 20$ & 20 \\
\hline$N$ & Missing 0 & 0 \\
\hline Rerata & 76,33 & 51,83 \\
\hline Standar & 10,20 & 10,29 \\
\hline Deviasi & & \\
\hline Nilai & 56,67 & 33,33 \\
\hline Terendah & & \\
\hline Nilai & 93,33 & 73,33 \\
\hline Tertinggi & & \\
\hline
\end{tabular}
untuk kelas eksperimen memperoleh nilai rerata sebesar 76,33 sedangkan kelas kontrol memperoleh nilai rerata sebesar 51,83, nilai standar deviasi kelas eksperimen sebesar 10,20 sedangkan kelas kontrol memperoleh sebesar 10,29, kelas eksperimen memiliki nilai varian sebesar 102,96 sedangkan kelas kontrol memiliki nilai varian sebesar 105,82 , nilai terendah kelas eksperimen adalah 56,67 sedangkan nilai terendah kelas kontrol adalah sebesar 33,33 dan nilai tertinggi kelas eksperimen 
sebesar 93,33 sedangkan nilai tertinggi kelas kontrol sebesar 73,33.

Pengujian persyaratan analisis terdiri dari uji normalitas data dan uji homogenitas data. Berdasarkan perhitungan data menggunakan program SPSS hasil uji normalitas untuk kelas eksperimen memperoleh nilai signifikansi $0,395 \geq 0,05$ yang berarti bahwa data tersebut berdistribusi normal. Untuk kelas kontrol memperoleh nilai signifikansi $0,824 \geq 0,05$ hasil ini menunjukkan bahwa data nilai kelas kontrol berdistribusi normal. Untuk uji homogenitas data memperoleh hasil signifikansi Rata-rata prestasi belajar kelas eksperimen dan kelas kontrol sebesar 0,986 $>0,05$ dan $\mathrm{F}$ hitung pada tabel 17 di atas sebesar 0,986 < 4,10 F tabel, dimana untuk taraf signifikansi 5\% dan nilai df1 adalah 1 dan nilai df2 adalah 38 maka $\mathrm{F}$ tabel sebesar 4,10 (F tabel lengkap dapat dilihat pada lampiran 15). Dengan demikian dapat disimpulkan bahwa data prestasi belajar kelas eksperimen dan kelas kontrol bersifat homogen.

Uji hipotesis kajian ini menggunakan Independent Sample T-Test pada program SPSS versi 22. Berdasarkan hasil uji t-test untuk nilai pre-tets didapat $t_{\text {hitung }}(1,414)<t_{\text {tabel }}(1,687)$ maka Ho diterima dan $\mathrm{Ha}$ ditolak dimana Ho berbunyi "Tidak ada perbedaan prestasi belajar siswa sebelum melaksanakan pembelajaran pada mata pelajaran PKK pada siswa kelas eksperimen maupun kelas kontrol". Berdasarkan hasil uji t-test untuk nilai post-test didapat $t_{\text {hitung }}(7,565)>$ $t_{\text {tabel }}(1,687)$ maka Ho ditolak dan $\mathrm{Ha}$ diterima dimana Ha berbunyi "Ada pengaruh prestasi belajar siswa yang diajarkan menggunakan MPK-BPKB dengan prestasi belajar siswa yang menggunakan model pembelajaran konvensional". Maka, besarnya peningkatan nilai prestasi belajar berdasarkan nilai rerata kelas pada kelas eksperimen adalah sebesar 31 .

Berdasarkan analisis data yang telah dipaparkan di atas, pembahasan hasil ini bertujuan untuk mendeskripsikan: (1) pelaksanaan MPK-BPKB di SMKN 2 Depok yang diantaranya deskripsi (a) tanggapan siswa terhadap pelaksanaan MPK-BPKB, (b) tanggapan guru terhadap pelaksanaan MPK-BPKB, (c) pengamatan peneliti terhadap penerapan MPK-BPKB, (2) pengaruh MPK-BPKB terhadap motivasi siswa, dan (3) pengaruh MPKBPKB terhadap prestasi belajar siswa.

Distribusi pelaksanaan MPK-BPKB pada mata pelajaran PKK menggunakan 10 tahapan pelaksanaan yang di tinjau dari tanggapan siswa terhadap guru yang mengajar mata pelajaran PKK kelas XI DPIB SMKN 2 Depok yang berjumlah 30 siswa. Berdasarkan deskripsi dan interprestasi data yang dilakukan dengan angket tertutup yang berjumlah 10 butir pertanyaan diperoleh hasil bahwa nilai rerata pelaksanaan MPK-BPKB secara keseluruhan pada mata pelajaran PKK adalah 1,62. Dengan demikian dapat disimpulkan bahwa pelaksanaan MPKBPKB pada mata pelajaran PKK di kelas XI DPIB SMKN 2 Depok ditinjau secara keseluruhan termasuk dalam kategori penjelasan cukup memadai yang artinya guru memberikan penjelasan kepada siswa cukup memadai.

Distribusi pelaksanaan MPK-BPKB pada mata pelajaran PKK menggunakan 10 tahapan pelaksanaan yang ditinjau dari tanggapan guru yang mengampu mata pelajaran PKK terhadap siswa-siswa di kelas XI DPIB SMKN 2 Depok. 
Berdasarkan deskripsi dan interprestasi data yang dilakukan dengan angket tertutup yang berjumlah 9 butir pertanyaan diperoleh hasil bahwa nilai rata-rata pelaksanaan MPK-BPKB secara keseluruhan pada mata pelajaran PKK adalah 2,56. Dengan demikian dapat disimpulkan bahwa pelaksanaan MPKBPKB pada mata pelajaran PKK di kelas XI DPIB SMKN 2 Depok ditinjau secara keseluruhan termasuk dalam kategori siswa melaksanakan dengan sangat baik yang artinya dalam pelaksanaan MPK-BPKB siswa telah mengikuti kegiatan pembelajaran menggunakan MPK-BPKB dengan sangat baik baik dari mengikuti proses pembelajaran maupun tes-tes yang diadakan oleh guru.

Pengaruh MPK-BPKB pada mata pelajaran PKK terhadap motivasi belajar siswa kelas XI DPIB SMKN 2 Depok yang ditinjau dari tanggapan siswa terhadap angket motivasi dengan jumlah 11 butir pernyataan. Berdasarkan deskripsi dan

\section{SIMPULAN}

Berdasarkan hasil kajian sesuai dengan tujuan yaitu mendeskripsikan pelaksanaan MPK-BPKB pada mata pelajaran PKK di kelas XI DPIB SMKN 2 Depok, mendeskripsikan apakah pelaksanaan MPK-BPKB meningkatkan motivasi belajar dan hasil belajar siswa, maka dapat disimpulkan sebagai berikut: 1) keterlaksanaannya tahapan-tahapan MPK-BPKB di kelas XI DPIB yang digunakan sebagai kelas eksperimen secara keseluruhan baik dari tanggapan siswa, guru dan peneliti dapat dikatakan pelaksanaan tahapan MPK-BPKB sudah memadai; 2) keterlaksanaan MPK-BPKB pada mata pelajaran PKK di kelas XI interprestasi data diperoleh rata - rata motivasi belajar siswa secara keseluruhan adalah sebesar 2,04 (dengan rentang $0-3$ ). Dengan demikian, tanggapan siswa terhadap angket motivasi siswa ada dalam rentang $(2,25>X \geq 1,5)$ atau memotivasi, yang artinya pembelajaran menggunakan MPK-BPKB memiliki pengaruh yang dapat memotivasi siswa dalam belajar mata pelajaran PKK.

Berdasarkan hasil rerata setiap kelas didapat peningkatan hasil belajar pada setiap kelas baik yang menggunakan MPKBPKB maupun yang menggunakan model pembelajaran konvensional. Peningkatan yang terjadi untuk kelas eksperimen adalah sebesar 31 dan untuk kelas kontrol meningkat hanya 9,66 saja. Maka dari itu penggunaan MPK-BPKB lebih efektif dalam meningkatkan hasil belajar siswa dan hasil belajar siswa dapat difungsikan juga untuk masyarakat banyak dengan produk yang sesuai dengan program keahlian yang di emban.

DPIB ditinjau dari peningkatan motivasi belajar siswa secara keseluruhan memiliki rata-rata sebesar 2,04 (dalam rentang 0-3), dengan demikian artinya pembelajaran menggunakan MPK-BPKB memiliki pengaruh yang dapat memotivasi siswa dalam belajar mata pelajaran PKK; dan 3) pengaruh MPKBPKB terhadap hasil belajar siswa kelas XI DPIB secara keseluruhan memiliki hasil uji syarat yang dapat dinyatakan normal dan homogeny. Hasil uji hipotesis untuk post-test $\mathrm{t}_{\text {hitung }}(7,565)>$ $t_{\text {tabel }}(1,687)$ maka Ho ditolak dan $\mathrm{Ha}$ diterima dimana $\mathrm{Ha}$ berbunyi "Ada perbedaan prestasi belajar siswa yang 
diajarkan menggunakan MPK-BPKB dengan prestasi belajar siswa yang menggunakan model pembelajaran konvensional". Peningkatan rerata hasil belajar pada kelas eksperimen (31) > kelas kontrol $(9,66)$ yang artinya

\section{DAFTAR RUJUKAN}

Arikunto, S. (2013). Prosedur Penelitian Suatu Pendekatan Praktik.Jakarta: Rineka Cipta.

Campbell, D.T., \& Stanley, J. C. (1963). Experimental and quasiexperimental design for research. United State of America: Houghton Mifflin Company.

Made Wena. (2009). Strategi Pembelajaran Inovatif Kontemporer. Jakarta: PT Bumi Aksara.

Mulyasa. (2015). Implementasi Kurikulum 2013. Bandung: PT. Remaja Rosdakarya.

Pratama, G. N. I. P. (2019, May). Basic communication skill drill in microteching context to improve the teching skills of civil engineering and planning education students, faculty of engineering, Yogyakarta State University. In IOP Conference Series: Materials Science and Engineering (Vol. 535, No. 1, p. 012014). IOP Publishing.

Pratama, G. N. I. P., \& Suparman, S. (2019). PENINGKATAN KETERAMPILAN MENGAJAR MAHASISWA PENDIDIKAN TEKNIK SIPIL DAN PERENCANAAN, FT, UNY MELALUI METODE DRILL BERBASIS KOMUNIKASI peningkatan hasil belajar menggunakan MPK-BPKB lebih baik dibandingkan menggunakan model konvensional atau ceramah.

VERBAL-NON VERBAL. Jurnal Pendidikan Teknik Sipil, 1(1).

Pratama, G. N. I. P., \& Triyono, M. B. (2015). Peningkatan kualitas pembelajaran prakarya dan kewirausahaan melalui metode CLTSMK. Jurnal Pendidikan Vokasi, 5(3), 313-324.

Retnawati, Heri. (2016). Analisis Kuantitatif Instrumen Penelitian. Yogyakarta: Parama Publishing.

Sugiyono. (2007). Metode Penelitian Kuantitatif Kualitatif dan $R \& D$. Bandung: Alfabeta.

Sugiyono. (2011). Statistika Untuk Penelitian. Bandung: Alfabeta.

Suryana. (2001). Kewirausahaan. Jakarta: Salemba Barat.

Trianto. (2010). Mendesain Model Pembelajaran Inovatif-Progresif. Surabaya: Kencana Prenada Media Grup.

Triyono, B. M., Mohib, N., Kassymova, G. K., Pratama, G. N., Adinda, D., \& Arpentieva, M. R. (2020). The Profile Improvement of Vocational School Teachers' Competencies. Vysshee obrazovanie $v$ Rossii= Higher Education in Russia, 29(2), 151-158. 